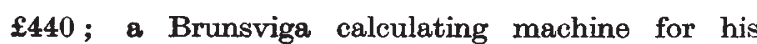
personal use had previously been presented to him. The bronze plaque, of which a copy is to be presented to University College, and a small reproduction to each subscriber, bears the following inscription : "Presented to Professor Karl Pearson, M.A., LL.D. F.R.S., by students, colleagues and friends on his retirement after having been a Professor of University College, London, for forty-nine years, in grateful commemoration of his research, teaching and inspiration." The balance of the fund is to be devoted to the completion or publication of such work of Prof. Pearson or his pupils as he may select or to the advancement in any other way of the branches of science with which his name will always be associated. Prof. Filon, in making the presentation, paid eloquent tribute to Prof. Pearson's distinction in so many fields, and was followed by Mr. G. Udny Yule, who gave very interesting personal reminiscences of work and holidays with "K. P.".

\section{Joseph Priestley}

THE recent issue of Isis (pp. 81-97) contains an important paper by Mr. W. Cameron Walker on "The Beginnings of the Scientific Career of Joseph Priestley", disposing of the incorrect views expressed by Priestley's biographers, such as, that his "History of Electricity" was suggested by Franklin and that it led to his election as F.R.S., that this distinction was the result of his electrical experiments, and so on. The Canton Papers and certain letters-some facsimiles are given-in the Royal Society's library show that the writing of the "History" was Priestley's own idea, that he was elected F.R.S. prior, not only to its publication, but also to his experiments, and that his friends secured his election with the view of increasing the sale of his book. Priestley's own account, written long after these events, ascribed his election to his original experiments. But the author is probably correct in hinting at a lapse of memory, since there is other evidence of this failing. The most interesting document here is Seddon's letter of December 18, 1765, introducing Priestley to Price and suggesting in a postscript his introduction to Franklin. As a result Priestley met Franklin and Canton, was elected F.R.S., was led to experiment in electricity, thence to the study of the conductivity of 'mephitic air', and thence to his classic chemical researches on 'airs' and to the discovery of oxygento the birth of modern chemistry. Few 'postscripts' have had such historic consequences.

\section{Trevithick Memorials}

A MEmorial to Richard Trevithick, the great engineer and inventor, was unveiled at Merthyr Tydfil on Thursday, April 19, by Mr. David E. Roberts, to mark in a fitting manner the historic journey of the first rail locomotive on February 21, 1804. The memorial is situated at Pontmorlais, close to. what was then the entrance gate to Penydaren Ironworks, where Trevithick built the locomotive. It ran down to the basin on the Glamorganshire Canal at Abercynon 9 $\frac{3}{4}$ miles distant, but the damage to the cast iron rails, which were of course only suited for horse traction, was such that the trials were not followed up. The memorial itself is built of stone sleepers taken from the track, and incorporates also some of the old rails. Its erection is the outcome of local effort backed by help from the Trevithick Centenary Commemoration in London. The event was made a civic occasion, and a concourse of upwards of 3,000 spectators assembled for the ceremony. The unveiling was followed by an address from Mr. Roberts on the work, especially that in South Wales, of Trevithick.

The second of the memorial tablets erected as a result of the commemoration last year of the centenary of the death of Trevithick, was unveiled at University College, London, on April 23, by the Hon. Oliver Stanley, M.P., Minister of Transport. The tablet has been placed on the Gower Street side of the College to mark the site of the track laid down in 1808 over which Trevithick's locomotive Catchme-who-can ran. This was the first rail locomotive to draw passengers, and the exact site of the experiment has only been determined after long inquiry. The tablet, which bears a medallion of the inventor, a representation of his engine and a suitable inscription, is of bronze; it is a bold and striking memorial and one which effectively attracts the attention of the passers-by. Prior to the unveiling, a meeting took place in the College which was presided over by Sir Murdoch Macdonald, M.P., the chairman of the commemoration committee. When asking Major Stanley to unveil the memorial, and the Provost of the College, Dr. Allen Mawer, to accept the custody of it, Sir Murdoch said that often our great benefactors have reaped but posthumous honours and so it was with Trevithick, for although he died in 1833, it was not until fifty years later that his memory was honoured by the erection of a window in Westminster Abbey. Methods of transport have developed greatly since Trevithick's time, but all our steam locomotives, great and small, work on the principle first effectively applied by him.

\section{Cosmic Rays}

Prof. P. M. S. Bracke'T delivered the Friday evening discourse on April 20 at the Royal Institution, taking as his subject "Cosmic Rays". This fascinating subject started more than thirty years ago with the discovery that clean dry air at sea-level is a slight conductor of electricity; it has now grown into one of the important branches of physics, and it perhaps may also be considered as an important branch of astronomy. For whatever the final explanation of the origin of the rays is found to be, it is probable that their origin is of great astronomical significance. The instruments with which the rays have been investigated have been the ionisation chamber, the counter and the cloud chamber, and experiments have been carried out with such apparatus all over the world and at very great heights above the ground and far below the surface. The cosmic radiation is a part, really, of geophysics, to be studied not only in the laboratory but also everywhere that is 
attainable. It appears from all these results that the earth is being bombarded by streams of positrons and electrons of very great energy. These appear to come continually from outside our galactic system, but from where, or how they are produced, no one knows. The study of the passage of these rays through the atmosphere has led to the discovery of exciting new phenomena. The positron, first detected by Anderson in a cloud photograph, is now known to be one of the main constituents of the rays ; and this now member of the group of fundamental par. ticles has very great theoretical interest, since its experimental detection has shown the validity of Dirac's theory of 'holes'. Very great interest is attached to the behaviour of the very fast cosmic ray particles while passing through matter. The curious and striking phenomenon of the 'showers' still awaits explanation. It is clear that one is here in a region of physics where quite new types of phenomena occur.

\section{Humour and Humanism in Chemistry}

UNDER this title, Prof. John Read, of the University of St. Andrews, gave an address to the Alchemists' Club of the University of Glasgow on February 28. One of the chief defects in the average science course or textbook, he said, is the neglect of the human element. He deprecated this omission, which he holds responsible for many of the misconceptions of men of science by their colleagues of arts and letters, "who, from attending a limited number of strictly formal and impersonal lectures on science have often deduced that the man of science is of necessity cold, formal and aloof; narrow in outlook; insensible to the finer human emotions; incapable of expressing himself in the common tongue; devoid of humour and humanism; and a stranger to the humanities." In the course of a picturesque survey of selected aspects of historical chemistry, Prof. Read claimed that the study of chemistry, if approached befittingly, may reasonably take rank beside the socalled 'humanities', as a broadly educative, cultural, and humanising influence. He re-defined humour in various terms as the golden thread running through the whole history of chemistry : the real philosopher's stone-the universal catalyst. The present generation of chemists, he remarked, are inclined to take themselves too seriously; like Liebig, Wöhler, and their more remote alchemical forebears, they should include a large pinch of humour and humanism in their curricula. The narrowness of outlook which is becoming increasingly associated with the ultraspecialistic trend of contemporary chemical research can be combated most effectively by the cultivation of an interest in the broader humanistic aspects of chemistry. Those chemists who aspire to become leaders in the future should cultivate a discerning and sympathetic acquaintance with the past. During the ensuing discussion, in reply to Prof. T. S. Patterson, the speaker threw some new light upon the possible origin and interpretation of the enigmatical seventeenth century illustrations appearing in the Mutus Liber.

\section{4-in. Telescope for the University of Toronto}

THE issues of Engineering for March 9 and 30 and April 20 contain a fully illustrated description of the 74-in. reflecting telescope now being completed by Messrs. Sir Howard Grubb, Parsons and Co., at Newcastle for the David Dunlap observatory of the University of Toronto. An account of the instrument was published in Nature of October 14, 1933. The observatory, which is being given as a memorial to the late David A. Dunlap, of Toronto, by his widow and son, is being erected on Richmond Hill, $800 \mathrm{ft}$. above sea-level, a few miles north of Toronto. The circular steel building and the 61-ft. dome for housing the telescope were made by Messrs. The Cleveland Bridge and Engineering Co., Ltd., at Darlington, and these together with the main parts of the telescope were sent to Canada last year. The polishing of the mirror is now in hand. The telescope, the largest in the British Empire and the second largest in the world, weighs about 50 tons, of which the moving parts account for about 35 tons. The polar axis is $22 \mathrm{ft}$. long and the declination axis $13 \mathrm{ft}$. long; the driving wheel on the former having a pitch diameter of $8 \mathrm{ft}$. with 960 teeth of $8 \mathrm{~mm}$. pitch. The article gives details of the driving and controlling mechanisms. The disc for the mirror, of special Pyrex glass, was made by the Corning Glass Works, New York, and when received at Newcastle weighed 2 tons 6 cwt. For grinding and polishing the mirror a special machine has been made which allows the mirror to be tilted for testing purposes without being removed from the machine. The telescope, it may be added, may be used either as a Cassegrain or a Newtonian, for which two mirrors 19 in. and 20 in. in diameter respectively are provided.

The David Dunlap Memorial telescope is illustrated in the issue of the Sphere dated April 21, which also ineludes photographs of the new 36-in. Yapp reflector at the Royal Observatory, Greenwich. Accompanying these illustrations is an article entitled "Studying the Sun in Calcium Light" and several lunar photographs taken with the 100 -in. reffector at Mount Wilson, California.

\section{Scientific Publication and Bibliography}

AN ambitious plan for scientific bibliography and publications is described in a memorandum issued by Science Service, Washington. The plan is designed to eliminate some of the defects in our present system, such as the difficulty of publishing research results promptly or completely owing to the financial burden, and the inadequacy of much bibliographic work owing to lack of access to original papers, etc. It is proposed accordingly to centralise all scientific publication, abstracting and similar bibliographic services, and to substitute a photographic type of duplication for printed reproduction of scientific papers or abstracts. Under this scheme a research report, for example, submitted and accepted for publication, would be reproduced from the standard typescript form by some suitable method other than printing, and full copies of the 